\title{
THE DECEMBER 28, 1989 NEWCASTLE, AUSTRALIA EARTHQUAKE D.R. Brunsdon*
}

\begin{abstract}
The December 28, 1989 Newcastle earthquake resulted in the loss of twelve lives and caused significant damage to many masonry buildings. Although Australia has previously experienced earthquakes of greater magnitude and intensity, this was the first such event to occur near a highly populated area in that country. While this earthquake is a relatively moderate event in international terms, it is nevertheless of particular interest to New zealand earthquake engineers and researchers and the insurance industry because of the social and organisational similarities between Newcastle and a number of large New zealand cities. The nature of the damage to buildings and services is summarised, along with insurance aspects and the response of local authorities.
\end{abstract}

\section{INTRODUCTION}

Newcastle is Australia's sixth largest city with a regional population of approximately 400,000 , and is situated $110 \mathrm{~km}$ north of Sydney. Established in the $1820^{\prime}$ 's, Newcastle has historically been a centre for heavy industry, with particular emphasis on coal mining and steel production, and has the third largest port facility in Australia.

The Thursday 28th December, 1989 earthquake occurred at $10.27 \mathrm{am}$, and was later determined to have a Richter magnitude of 5.6. Seismologists estimated the epicentre of the earthquake to be at Boolaroo, a suburb $14 \mathrm{~km}$ west-south-west of the city centre (refer figure 1), with the focus considered to be at a depth of $11 \mathrm{~km}$.

The greatest damage to buildings was recorded in the Central Business District of Newcastle and the adjacent inner city suburbs. The intensity of ground motion appears to have peaked in this area at between MMVII and MMVIII on the Modified Mercalli scale. Comparatively little damage to major civil engineering structures and lifeline services was recorded. The earthquake was felt over a radius of approximately $310 \mathrm{~km}$ as illustrated in the isoseismal map in figure 2 .

\footnotetext{
* Irwin, Johnson and Partners,
} Sydney, Australia
There were twelve deaths recorded as a result of this earthquake, and more than one hundred people required hospital treatment for injuries.

The most recent estimates by the Insurance Council of Australia put the total insurance costs to be in the range $A \$ 700-800$ million. Cyclone Tracy was the previous largest Australian natural disaster event in insurance terms, with an equivalent total insurance cost of $\mathrm{A} \$ 650 \mathrm{million}$.

Immediately following the earthquake, the New Zealand Government offered the New South wales state Government assistance in the form of the services of experienced earthquake engineers for advice during the post-event recovery process. As a result the president of the Society, Mr Bruce Shephard and another Society member, Mr Brian wood arrived in Newcastle on December 30 for a period of two weeks and one week respectively. Their main role was working with Public Works Department engineers in assessing the damage to public buildings, setting up posting procedures and recommending restoration and strengthening techniques, in addition to assisting the Newcastle city Council in damage assessments and establishing posting procedures. A number of other society members including the writer were also active in Newcastle during this and subsequent periods, working for the public Works Department, Newcastle city Council and the private sector. 


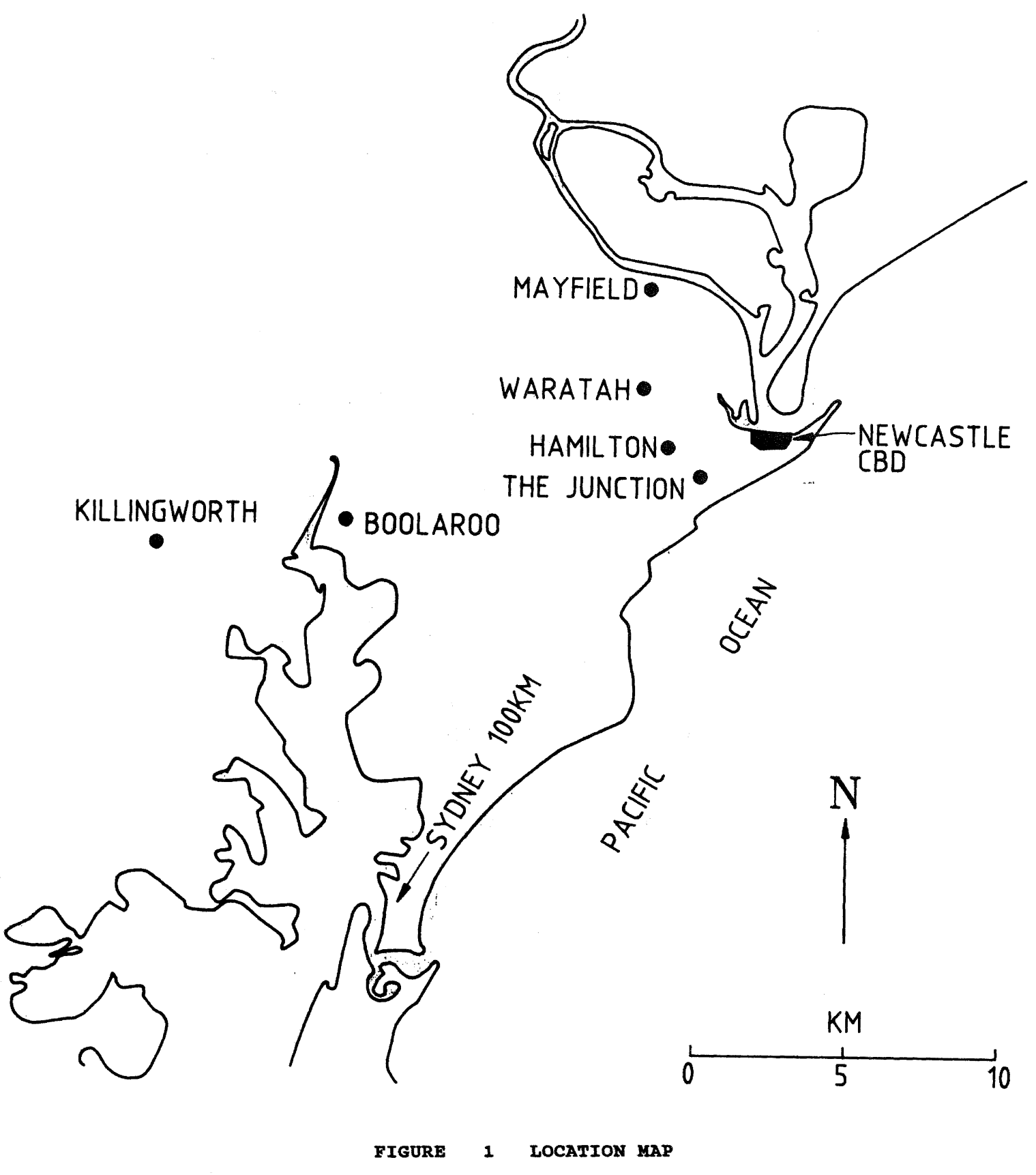

\section{GEOLOGX OF THE NEWCASTLE REGION}

The geology of the Newcastle region features a range of different rock types beneath the surface layers, with conglomerates, sandstones, shales and coal seams all present. The underlying sedimentary rocks are at the northern extent of the sydney Basin and are approximately 4-5 km below surface level. There is surface evidence of previous faulting, and vertical fractures in the crystalline bedrock are reflected through to the surface in some areas.
The predominant geological feature that influenced the extent of damage to buildings in this earthquake was the variation in depth of the alluvial material overlying the bedrock. There is a strong correlation between the areas where MM VIII intensities were recorded and the zones of deep alluvium and fill as illustrated in figure 3. The central city and inner suburbs are located over fluvially deposited sandy layers of varying densities with occasional peaty deposits. These layers have total thicknesses in the range 10-20m in the inner suburban areas of Hamilton and The Junction where the worst building damage was recorded. 
ISOSEISMAL MAP OF THE NEWCASTLE EARTHQUAKE NEW SOUTH WALES, 28 DECEMBER 1989
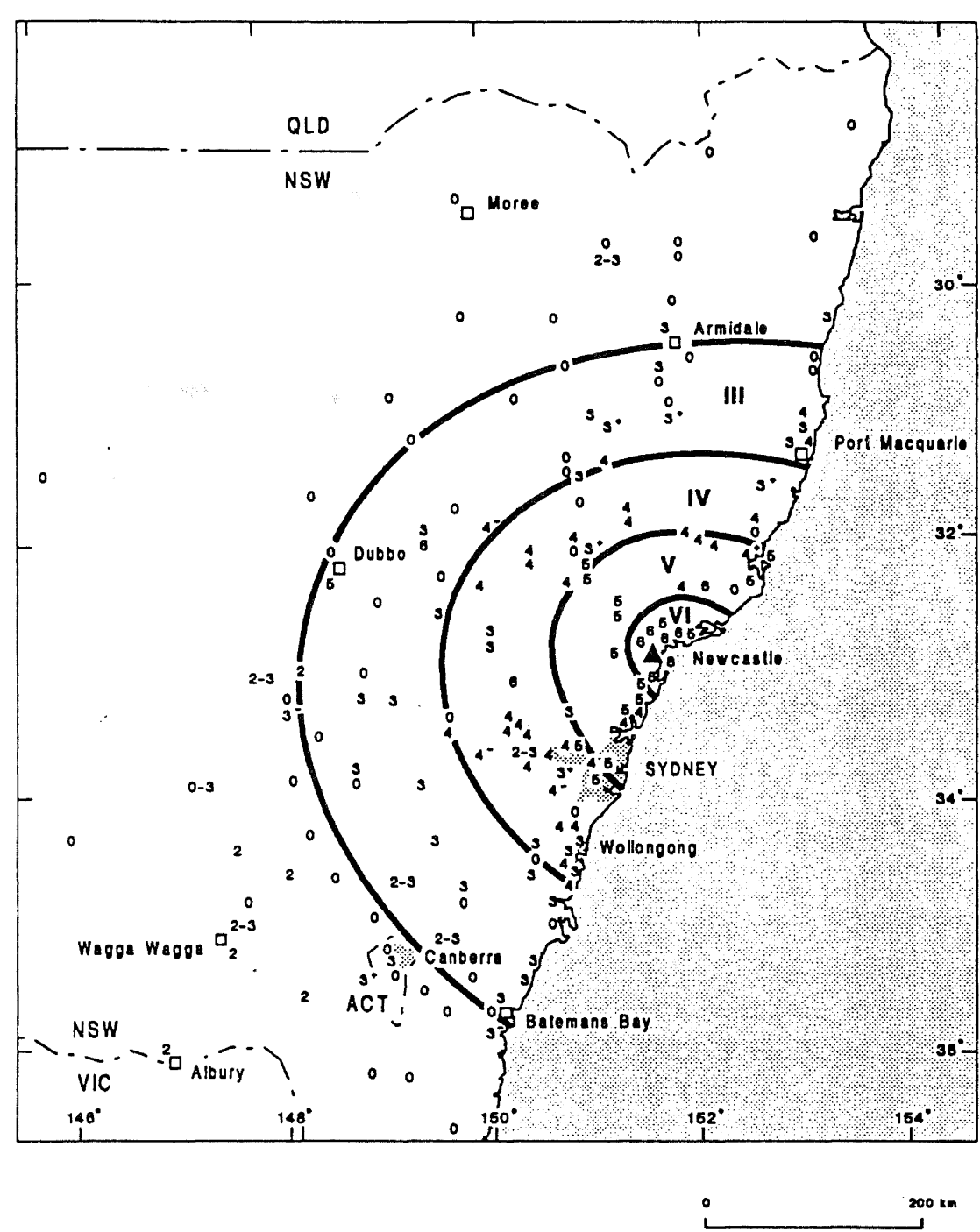

DATE : $\quad 28$ Decombor 1989

'TIME : 23:26.58 $1.5 \mathrm{~s}$ UTC

MAONITUDE : $5.6 \mathrm{ML}$

EPICENTRE : $92.95^{\circ} \mathrm{S}, 151.61^{\circ} \mathrm{E}$

DEPTH: $\quad 11.5 \pm 1.0 \mathrm{~km}$

$\triangle$ Eplcentre

IV Zone Intonsity Designation

3 Earthqusko Folt (MM)

- Earthquako Not Folt

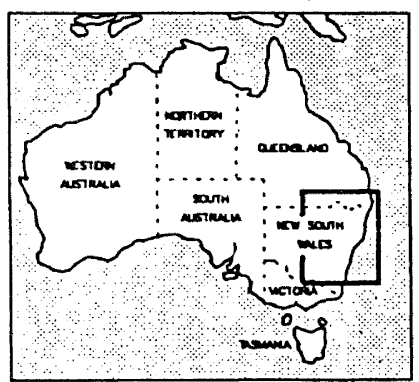




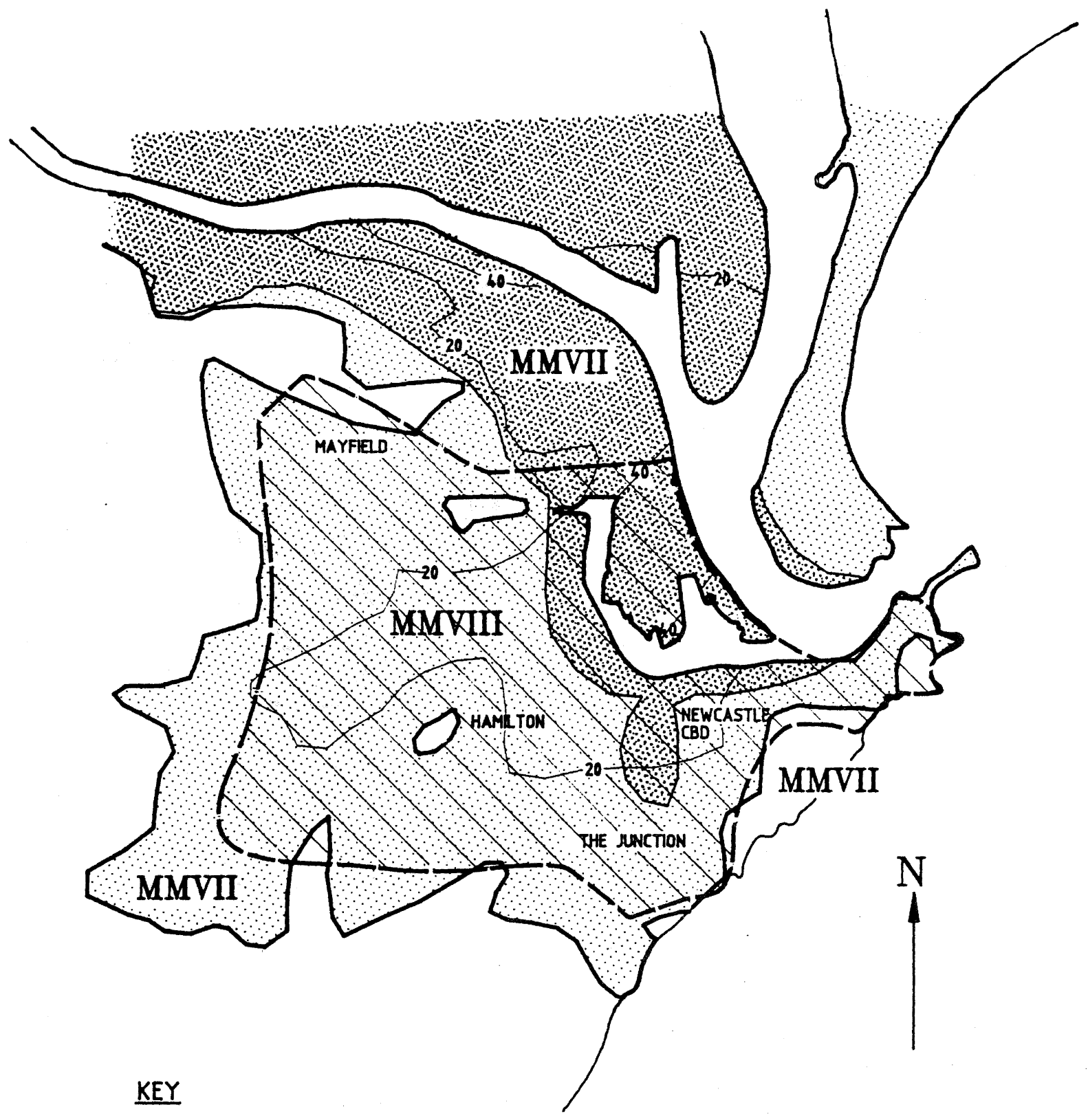

$\square \quad$ RESIDUAL SOIL/ROCK AREA

ALLUVIAL AREA

FILL OVERLYING ALLUVIAL AREAS

- ALLUVIAL THICKNESS CONTOURS (M)

FIGURE 3 RELATIONSHIP BETWEEN AREA OF GREATEST DAMAGE AND ALIUVIAL REGION (MODIFIED FROM [3]). 


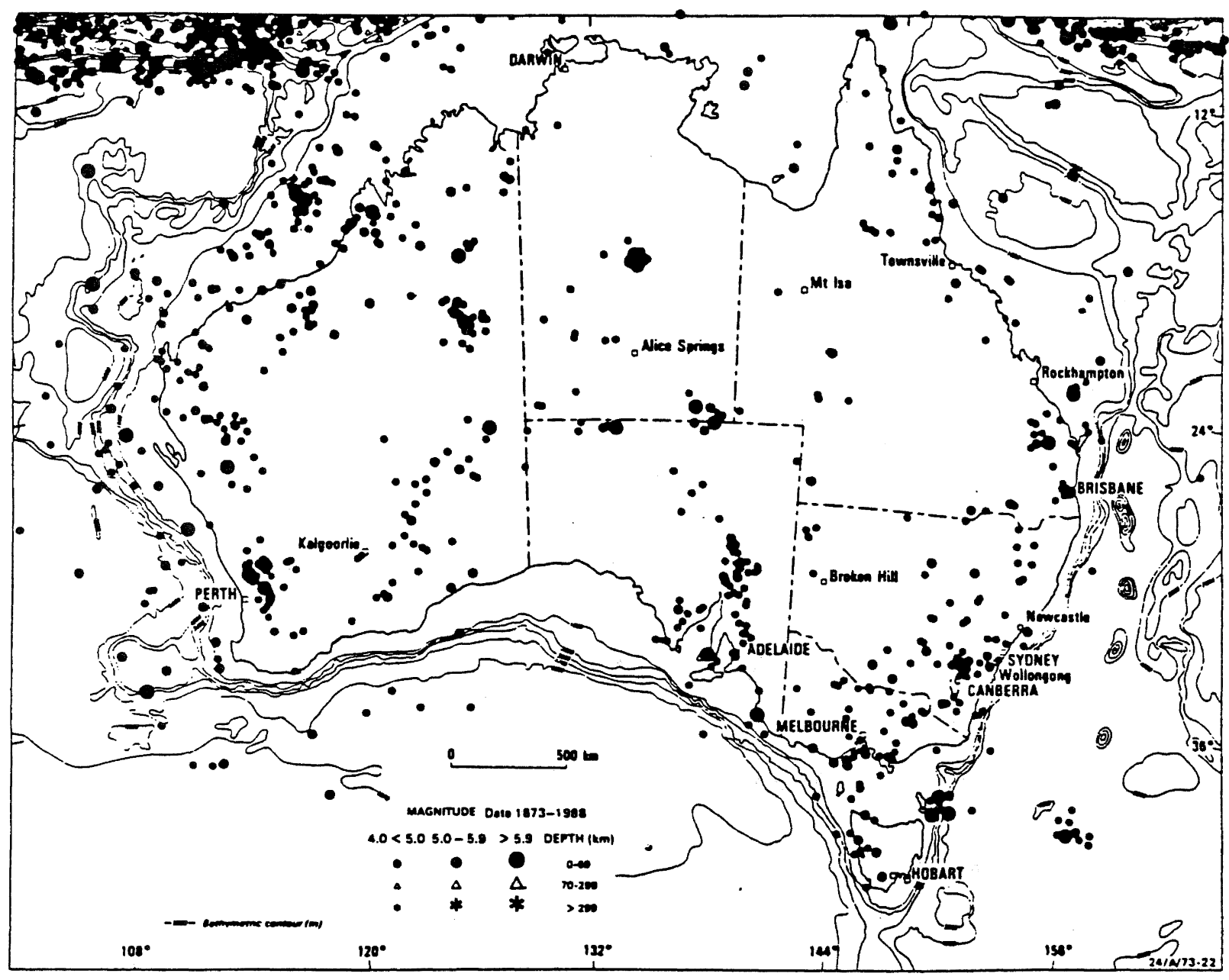

FIGURE 4 AUSTRALIAN EPICENTRES 1873-1988 MAGNITUDE 4 OR GREATER (AUSTRALIAN BUREAU OF MINERAL RESOURCES)

The main industrial area adjacent to Newcastle Harbour features extensive areas of fill above the natural sediments, with the underlying rock being up to $40 \mathrm{~m}$ below surface level. Elsewhere the rock stratum is overlain with residual soils. There are local suburban areas where reactive (expansive) clays are known to be present, but their properties did not appear to significantly influence building response.

A prime characteristic of this earthquake was the absence of any discernible rupturing of the ground surface, which emphasises the depth of the epicentre. No observations of liquefaction of sands were reported, although it is considered that liquefaction may have occurred in certain areas had the earthquake been of longer duration.

There are numerous coal seams in this region with extensive disused underground workings, particularly in the inner city area. However as nearly all of the tunnels are now waterfilled, there were few instances of building damage caused or exacerbated by the collapse or settlement of workings. In one case where a house had been constructed over a water filled mine rising shaft, the earthquake generated suction forces within the shaft which caused extensive internal damage to the building.

There were several reports of ongoing movement of damaged buildings in the weeks following the earthquake. These typically occurred in areas of deep alluvial layers, and the movement was considered to be the result of gradual settlement of the predominantly sandy material beneath shallow footings continuing after the initial ground motion. Many older domestic footings consisted of loose-laid bricks which may have taken time to assume their final at-rest position.

Although the month following the earthquake was generally dry, the weekend of February 23 saw the region receive a near-record deluge of rain. Following this, some observations of landfill slumping and escarpment movements were recorded, but the earthquake was not considered to have been a direct influence on these events. 
TABLE 1: SUMMARY OF LARGE AUSTRALIAN EARTHQUARES

(Australian Bureau of Mineral Resources [4])

LOCATION

YEAR

RICHTER

MAGNITUDE

\begin{tabular}{lll}
\hline Meeberrie (WA) & 1941 & 7.2 \\
Meckering (WA) & 1968 & 6.9 \\
West Tasman Sea & 1892 & 6.9 \\
West Tasman Sea & 1885 & 6.8 \\
West Tasman Sea & 1884 & 6.4 \\
Tennant Creek (NT) & 1988 & $6.3,6.4,6.7$ \\
Beachport (SA) & 1897 & 6.5 \\
Queensland & 1918 & 6.3 \\
Cadoux (WA) & 1979 & 6.2 \\
Gayndah (QLD) & 1935 & 6.1 \\
Marryat Creek (SA) & 1986 & 6.0
\end{tabular}

\section{SEISMOLOGICAL FEATURES}

Although Australia is not commonly regarded as a seismically active country in comparison to others around the pacific rim as the continent lies entirely within the Australian plate, it has experienced major earthquakes at regular intervals since records began. Figure 4 indicates the recorded location of earthquakes greater than magnitude 4.0 in Australia, and Table 1 lists the currently identified earthquakes of magnitude greater than 6.0.

Previous major events causing significant damage include the Meckering, Western Australia earthquake of 1968 , and the Tennant Creek, Northern Territory earthquake of 1988 , which featured three separate events on the one day. Both of these earthquakes caused local surface faulting of up to two metres vertically.

Recent work by Australian seismologists has widened the earthquake data base by using felt reports in contemporary late nineteenth and early twentieth century newspapers to prepare isoseismal maps to identify epicentres and magnitudes of events that occurred before the establishment of the modern network of seismographs. In the seismically active Gunning - Dalton region of New South wales near Canberra, over one hundred years of earthquake record has now been established [1], leading to the estimation of a 120 year return period for a magnitude 6.0 earthquake for this area.

Figure 4 also highlights that the sydney Newcastle eastern seaboard region has previously experienced several major earthquakes. In 1868, a magnitude 5.3 earthquake was centred close to Newcastle, and a similar magnitude event occurred near Boolaroo in 1925 .

There is a significant lack of seismic instrumentation throughout Australia generally including the Newcastle region and this both hindered the immediate post-event analysis and restricted the extent and quality of information recorded from this earthquake. The nearest seismograph was located at sydney, while there was no strong motion equipment at all in the region [2].

The variation in depth of the alluvial layers and hence ground motion suggests that a large number of strong motion accelerographs would have been necessary to accurately map the range of and peak ground velocities and accelerations experienced. Based on comparisons of MM intensities from adjacent rock and alluvial areas, empirical estimates suggest an average amplification factor of between two and four is attributable to the alluvial material [3].

In the absence of any other indications as to the risk of aftershocks occurring, old newspaper reports of the two previous Newcastle earthquakes were obtained. The articles made no mention of aftershocks following those events, and in this case only one small immediate aftershock of magnitude 2.1 was recorded on December 29 , with another of magnitude 2.0 occurring on February 23 [2]. In the two days immediately following the earthquake, representatives from the Australian Seismological centre and the Phillip Institute installed ten seismographs around the Newcastle area in order to monitor and locate the source of any aftershocks. 
The epicentre was initially considered to be in the inner city suburb of Hamilton, due to the concentration of MMVIII damage in one particular street. However analysis of information from various sources including seismograms from scotland defined the focal depth as $11 \mathrm{~km}$, and from this the epicentre was calculated to be $14 \mathrm{~km}$ distant at the suburb of Boolaroo [2]. The severity of damage in some areas led to the initial observation that this was a shallow earthquake, but more detailed analyses confirmed that it was of deep origin with the surface geology being the governing factor in terms of damage extent.

The principal stress direction of the earthquake was northeast-southwest with the preferred fault plane striking northwestsoutheast and dipping steeply to the northeast [2].

\section{AUSTRALIAN SEISMIC DESIGN PROVISIONS}

Seismic design in Australia is governed by the SAA Earthquake Code, AS 2121:1979 [5]. The philosophies and provisions of this code are generally based on the SEAOC codes with details taken from the U.S. Uniform Building code (UBC).

AS2121 covers buildings in general but excludes small domestic structures. Although mention is made of existing buildings, the code is not retrospective and requires only that additions or alterations do not reduce the lateral load capacity of the original structure.

Four seismic zones are defined by As2121 (refer figure 5), with zone numbers correlating with the UBC zone numbers in terms of seismic resistance philosophy.

The design requirements of each zone are summarised as follows:

ZONE 0: Covers areas not otherwise defined; no earthquake resistance requirements.

ZONE A: Ductile construction - no horizontal force levels specified.

Non-ductile construction - elastic force levels specified $(K=3.2)$

(note that ductile construction is defined as being reinforced concrete or masonry and steel detailed in accordance with the respective SAA materials codes)

ZONE 1 \& 2: Horizontal force levels specified for ductile and non-ductile construction (50m height limit for non-ductile construction)

For ductile moment-resisting space frames detailing is either to be in accordance with section 2626 of UBC, or a $50 \%$ higher force factor can be used with less onerous detailing to be in accordance with the SAA Concrete Design Code, AS1480 [6]. This code, which permits the use of $90^{\circ}$ stirrup anchorages, is in the process of being replaced by a completely revised concrete design code, AS3600 [7], which requires that all stirrups be anchored with $135^{\circ}$ returns in addition to other design and detailing improvements.

All reinforced concrete shear walls are assumed to behave in a ductile manner, although the principles of capacity design and related detailing requirements are not mandatory. Reference is made to section 11.10 of ACI Standard 318-77 for designing and detailing walls for shear. There is a height limit of $50 \mathrm{~m}$ for ductile reinforced masonry walls where there are no other ductile elements present to resist seismic loading.

This code stipulates that post-disaster function buildings in Zone 2 shall not be of non-ductile construction.

Earthquake forces may be determined using either dynamic analysis or the quasi-static approach detailed in the code. There are no specified limits restricting the application of the quasi-static method. The minimum total earthquake horizontal force, $H$ for this approach is defined as follows:

Where

$$
\begin{aligned}
\mathrm{H}= & (\text { ZIKCS) } \times \text { Building Seismic } \\
& \text { Weight } \\
\mathrm{Z}= & \text { Zone factor } \\
= & 0.09 \text { Zone A (non-ductile } \\
& \text { construction) } \\
= & 0.18 \text { Zone } 1 \\
= & 0.36 \text { Zone } 2
\end{aligned}
$$

$I=$ Importance factor

$=1.0$ Generally

$=1.2$ Essential facilities

$\mathrm{K}=$ Horizontal force factor ranging from 0.67 for fully detailed moment-resisting space frames to 3.2 for non-ductile construction

$C=$ Seismic response factor

$=1 / 15 \mathrm{~T}$ but not greater than 0.12

$S=$ Site-structure resonance factor $=1.5$ or as calculated as a function of the ratio of building structure period to characteristic site period. Note that this factor relates to soilstructure interaction only, and does not account for potential amplification of ground motion within areas of alluvial and/or fill material.

A minimum force level is defined as 0.02 times the building seismic weight for zones $A, 1$ and 2 .

It can be seen from figure 5 that none of the main centres lie in Zone 2, with Adelaide located in Zone 1 and Perth and the majority of sydney situated in zone A. Newcastle, along with Melbourne and Brisbane is currently zoned 0 . 


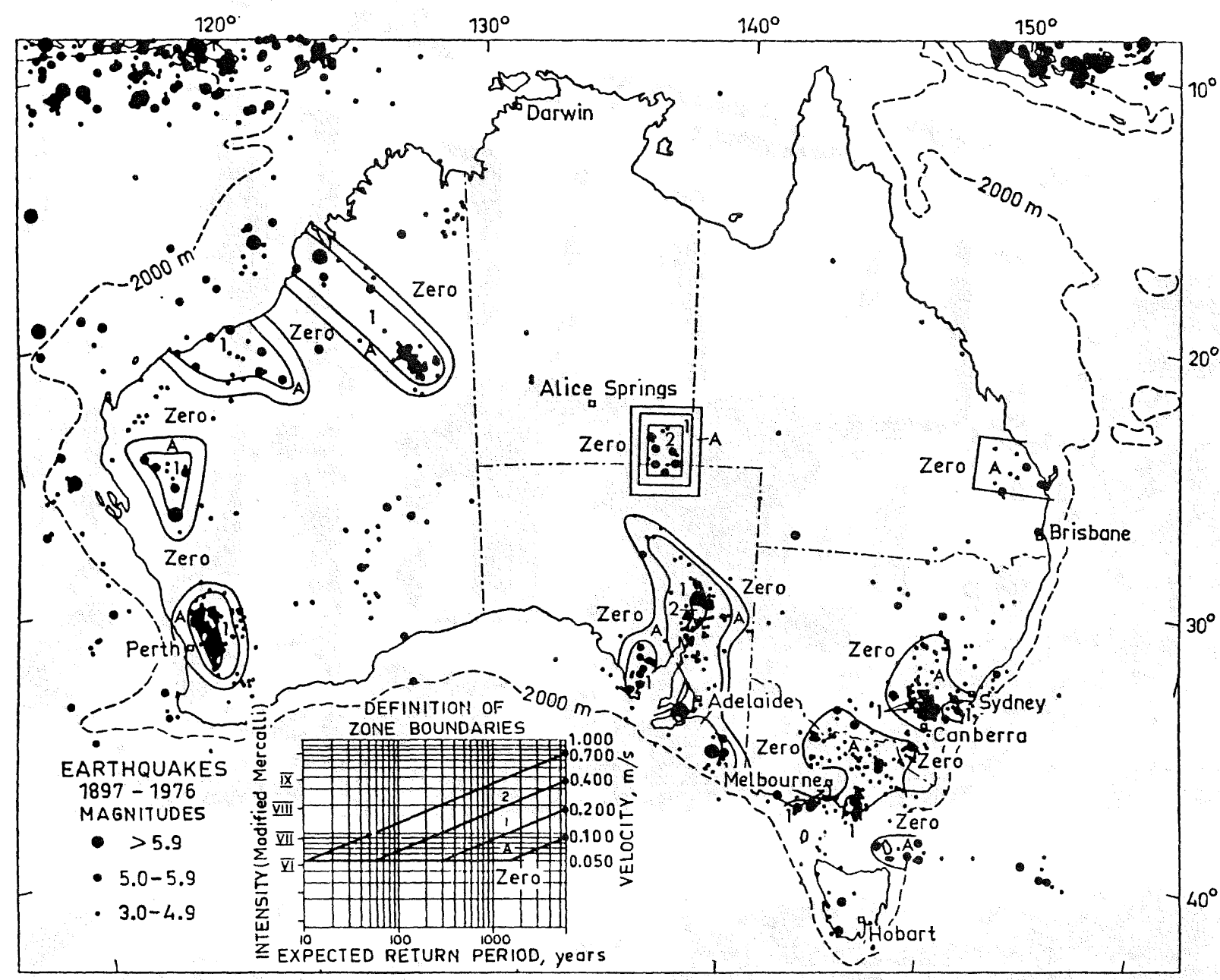

FIGURE 5 SEISMIC ZONE MAP OF AUSTRALIA [5]

As a rudimentary comparison of the seismic design levels required by AS2121 and the New Zealand Loadings Code, NZS4203:1984 [8], consider two equivalent 20 storey reinforced concrete ductile cantilever shear wall buildings in Adelaide and Auckland respectively, which are both assumed to be situated over intermediate subsoils. Based on the AS2121 zone 1 requirements, the Adelaide building would attract a seismic coefficient of 0.012 , although this is overridden by the minimum coefficient requirement of 0.02 as above. This compares with a seismic coefficient of approximately 0.04 for the Auckland building in New Zealand Seismic Zone $C$.

It should be noted that the adoption of specific design standards in Australia is the responsibility of the individual states. As a result, AS 2121 is currently mandatory only in western Australia and Southern Australia, although all commonwealth (Federal) Government buildings are designed according to its provisions. This situation is intended to be rectified with the adoption of the new Building Code of Australia which standardises design codes and other building regulations.

\section{SUMMARY OF DAMAGE TO BUILDING STRUCTURES AND SERVICES}

The earliest commercial buildings in Newcastle were constructed in the 1840's with some domestic buildings dating back to the turn of the nineteenth century. Many early buildings featured elaborate masonry detailing appropriate to the respective eras, often including tall cantilevering parapets. Although the Central Business District of Newcastle now features many buildings of a more modern vintage, the inner suburbs where the greatest damage was recorded contain a high proportion of original masonry buildings, many of whom are nearing the end of their economic life.

The use of unreinforced masonry is widespread 


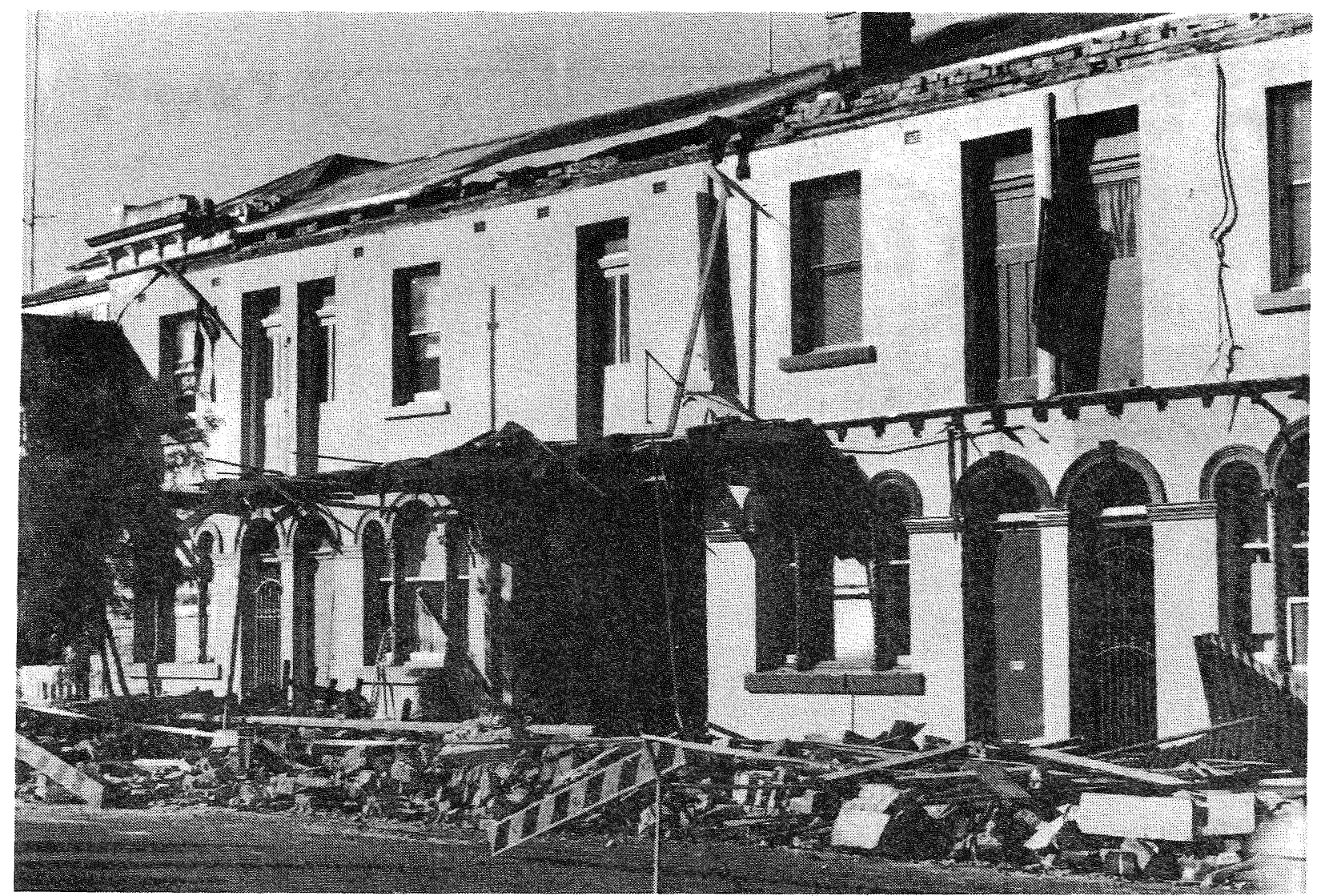

FIGURE 6 PARAPET AND AWNING FAILURE - RESIDENTIAL BLOCR

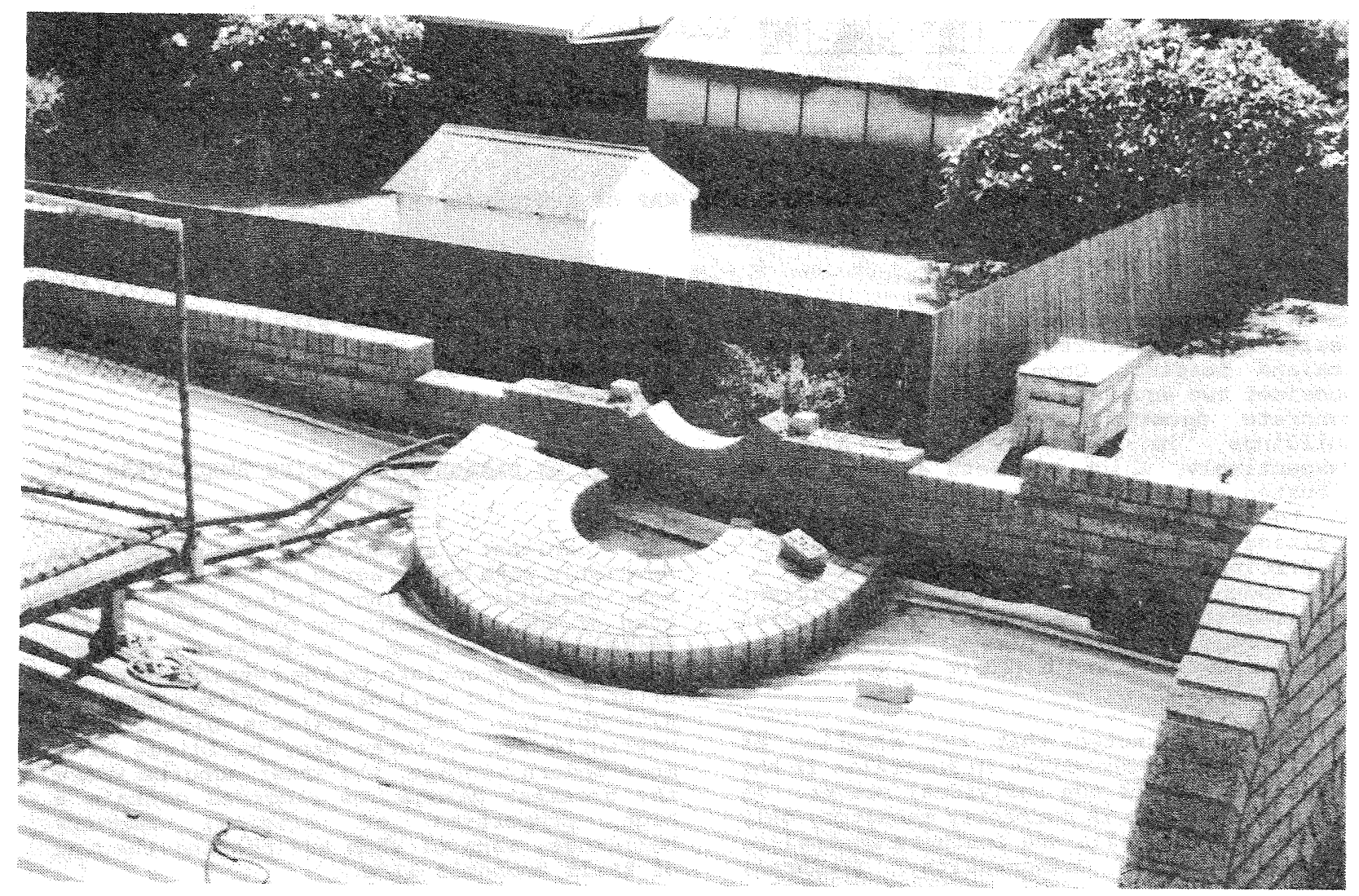

FIGURE 7 PARAPET FAILURE - MODERN RETAIL BUILDING 


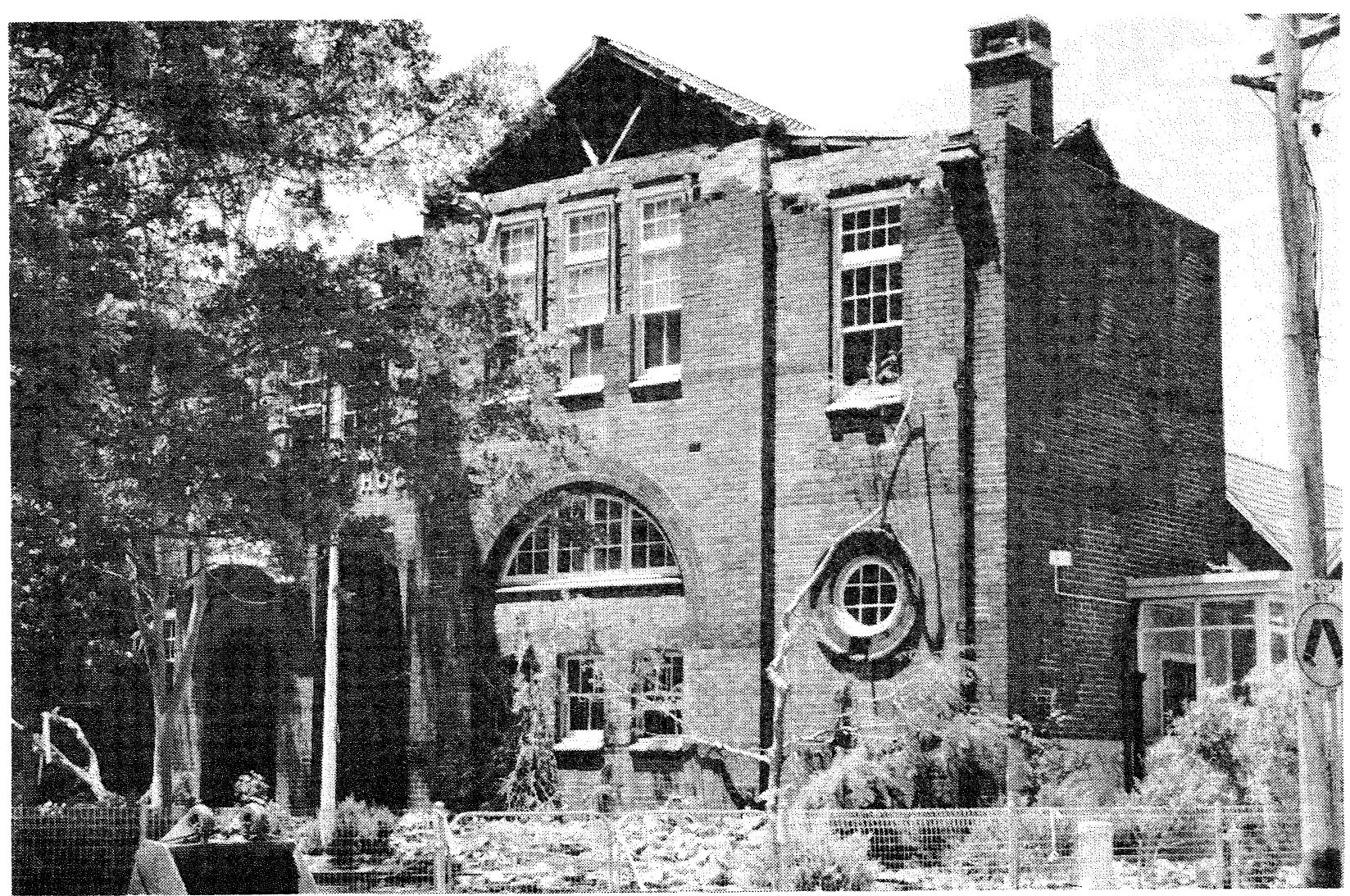

FIGURE 8 GABLE END FAILURE - THE JUNCTION SCHOOL

in old and modern buildings alike in Australia. Consequently there are several damage characteristics common to all categories of buildings. The majority of building damage resulted from a lack of lateral restraint to masonry elements, leading to failure modes experienced and identified in more earthquake-prone countries.

The building elements that most commonly suffered damage can be summarised as follows:

\section{Parapets}

Parapet failure was the most common form of masonry damage, and posed the greatest hazard to members of the public. Figure 6 shows a residential building block which illustrates the outcome of a common facade failure mode. The high - level parapet had fallen outwards onto the tied awning below, which in turn pulled out of the brick walling above first floor level, with all of the debris ending up on the footpath. Deaths resulted from this mechanism in Beaumont street, Hamilton with other casualties recorded elsewhere. Ironically, many of the tied awnings were originally supported by posts at the kerbline, but cases of collapse caused by motor vehicles led to state legislation requiring the removal of such posts being passed in the $1950^{\prime} \mathrm{s}$.
Inadequately detailed modern masonry parapet elements also failed, with an example taken from a two-year-old retail building in Hamilton shown in figure 7 .

\section{Gable Ends}

The collapse of inadequately tied gable ends also occurred in a wide range of buildings, notably in early schools with steeply pitching roofs and hence large gable areas (refer figure 8 ). However this type of damage was also observed in more modern domestic and industrial buildings, illustrating that the basic principles of lateral restraint in construction were not always being followed. Typically the gable brickwork was only butted up against the roof timber framing, with nominal toothing-in of the ridge beam and rafters. For the prevalent case of outward falling gables, this detail appeared to offer insufficient restraint to resist design wind suction forces.

Fortunately in many cases the roof framing comprised trusses parallel to the gable ends, so that progressive collapse was avoided. However this gave rise to several cases in the CBD where the buildings that had lost gables suffered little additional damage, but neighbouring premises were extensively damaged by the falling brickwork. 


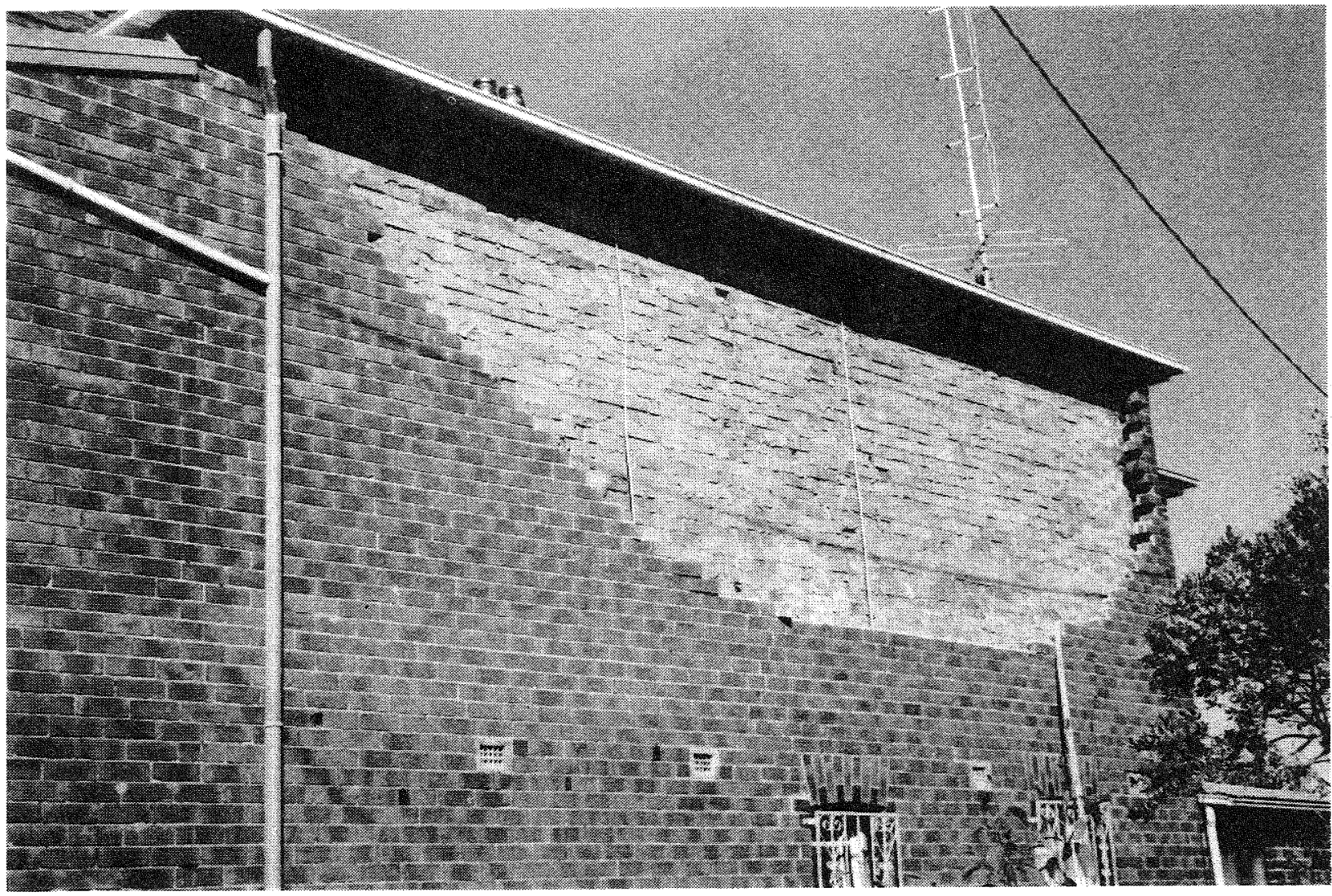

FIGURE 9 FAILURE OF OUTER SKIN OF CAVITY BRICK WALL

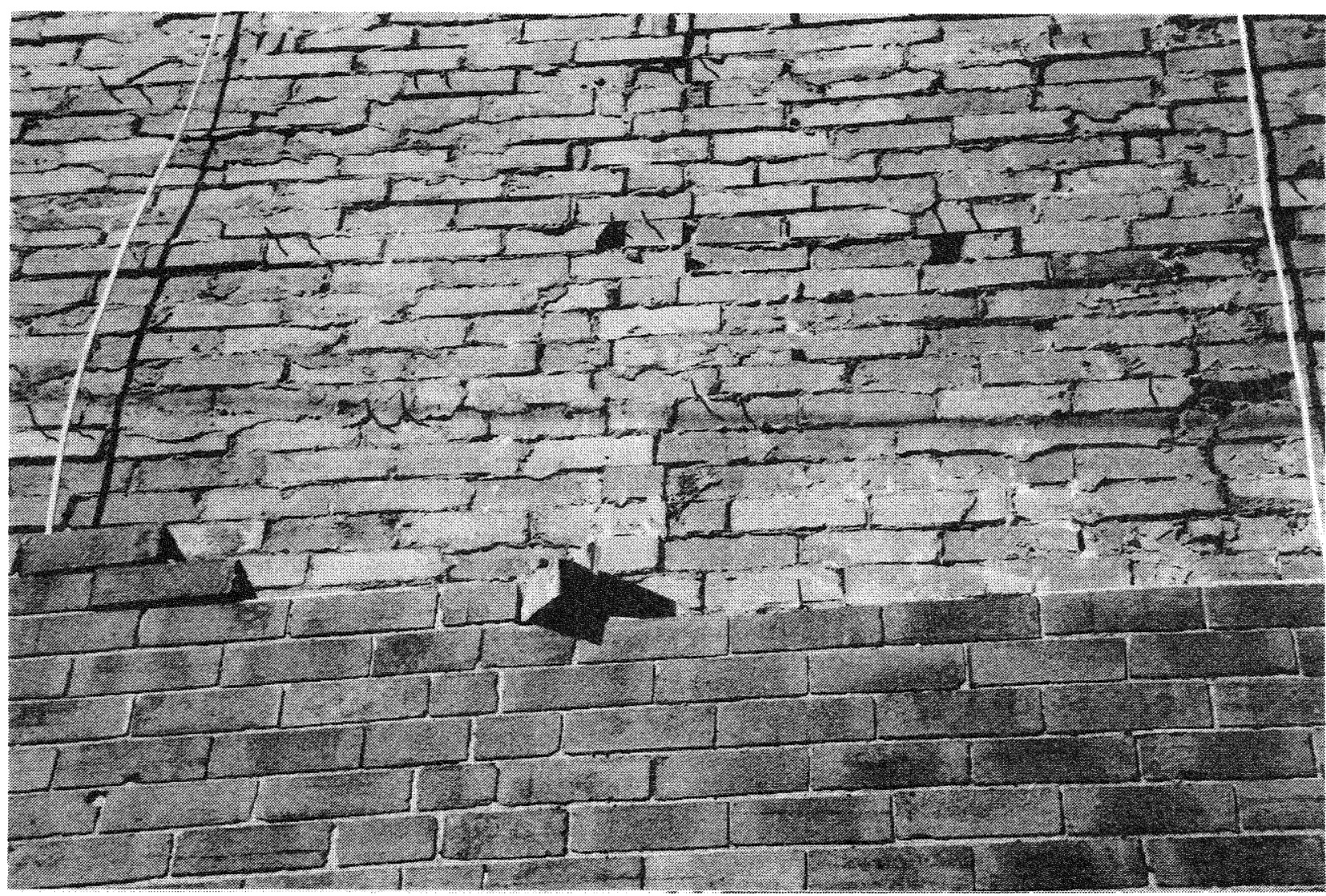




\section{Outer Skins of Cavity Brick Walls}

The failure of sections of outer skins of cavity brick walls was due principally to severely corroded cavity ties (refer figure 9). The harsh coastal and industrial atmospheric conditions appear responsible for this corrosion which often rendered the ties totally ineffective (refer figure 10), despite many ties being galvanised originally.

A related problem for all early masonry was the extensive use of lime mortar. The inclusion of lime caused the degeneration of the mortar to a friable state, clearly with negligible bond strength and unable to offer any protection to the embedded cavity ties.

\section{Chimneys}

Chimneys suffered varying degrees of damage, with several old large industrial and institutional chimneys requiring either partial or total demolition.

Damage to brick parapets and gables illustrated the directionality of the earthquake, with the northeast southwest facing elements faring worst.

Within the greater Newcastle area, approximately 25,000 buildings of all categories sustained some form of damage as a result of the earthquake, with 10,000 suffering moderately severe damage. It should be emphasised that if this had not been such a relatively short duration event, many of these badly damaged buildings would have collapsed due to a lack of reserve capacity.

\section{Commercial and Retail Buildings}

The Central Business District of Newcastle contains twenty buildings of greater than six storeys in height, with an estimated $60 \%$ of the total building stock being greater than two storeys. This latter figure includes a large number of masonry buildings of up to five storeys in height.

Very few modern buildings received extensive structural damage, apart from instances previously noted of damage from adjacent falling masonry. Notable exceptions include the Newcastle Workers' Club, where the majority of deaths occurred and the Junction Motel, a reinforced concrete frame structure which was subsequently demolished.

The Workers' Club building consisted of sections of various ages and types of construction, and it was a newer, predominantly reinforced concrete section that collapsed. There are several theories as to the cause and mechanism of the collapse, with conclusions expected to be drawn at the forthcoming coronial inquiry.

The nine-year-old Junction Motel suffered severe translational damage in the bottom car park level, and was considered to be beyond repair. Although there were masonry infill bracing panels in this storey, they did not appear to offer any effective drift control, and several columns failed in various modes at the underside of the first floor.

Several modern commercial premises suffered damage to secondary (non-structural) elements. Internally this included cracking of plasterboard and masonry partition walls, particularly where they adjoined main structural elements, and the loss of ceiling tiles.

There was significant in- and out-of-plane damage to the upper level walls of some older masonry buildings greater than two storeys in height within the CBD. Other one- and twostorey early masonry commercial and retail buildings in both the $C B D$ and Hamilton suffered typical damage as described in the previous section.

Some of the tall brickwork parapets of the early multistorey commercial buildings already contained major cracking, which gave rise to parapet failures under earthquake loading as noted previously. Typically these parapets had been constructed continuously around all sides of the buildings, with no allowance for thermal or brick growth expansion. This had led to large vertical cracks forming near the corners, further reducing the lateral load capacity of the parapets.

\section{Residential Buildings}

The majority of residential construction in Newcastle consists of single and doublestorey detached dwellings. older - style terrace housing is generally restricted to the inner suburbs, where a limited number of multistorey residential buildings are also situated. This latter category did not suffer extensive damage, despite commonly featuring the classic variation in both storey and directional stiffnesses. Significant lateral drifts were recorded in the bottom (car parking) floor of two apartment buildings as a consequence of the absence of cross walls in one direction.

However a large number of detached and terrace houses sustained earthquake damage. While older houses in the inner suburbs generally received the greatest damage, many newer houses in these areas above deep alluvial layers were also hard hit. The geographical distribution of damage to residential premises in the greater Newcastle area is illustrated in figure 11. This figure is based on data compiled from the analysis of domestic earthquake insurance claims by the National Roads and Motorist's Association (NRMA), which is the largest insurer of domestic property in New South wales.

In addition to the typical damage characteristics noted previously, many older houses suffered extensive cracking of the internal rendered brick walls and ceiling 


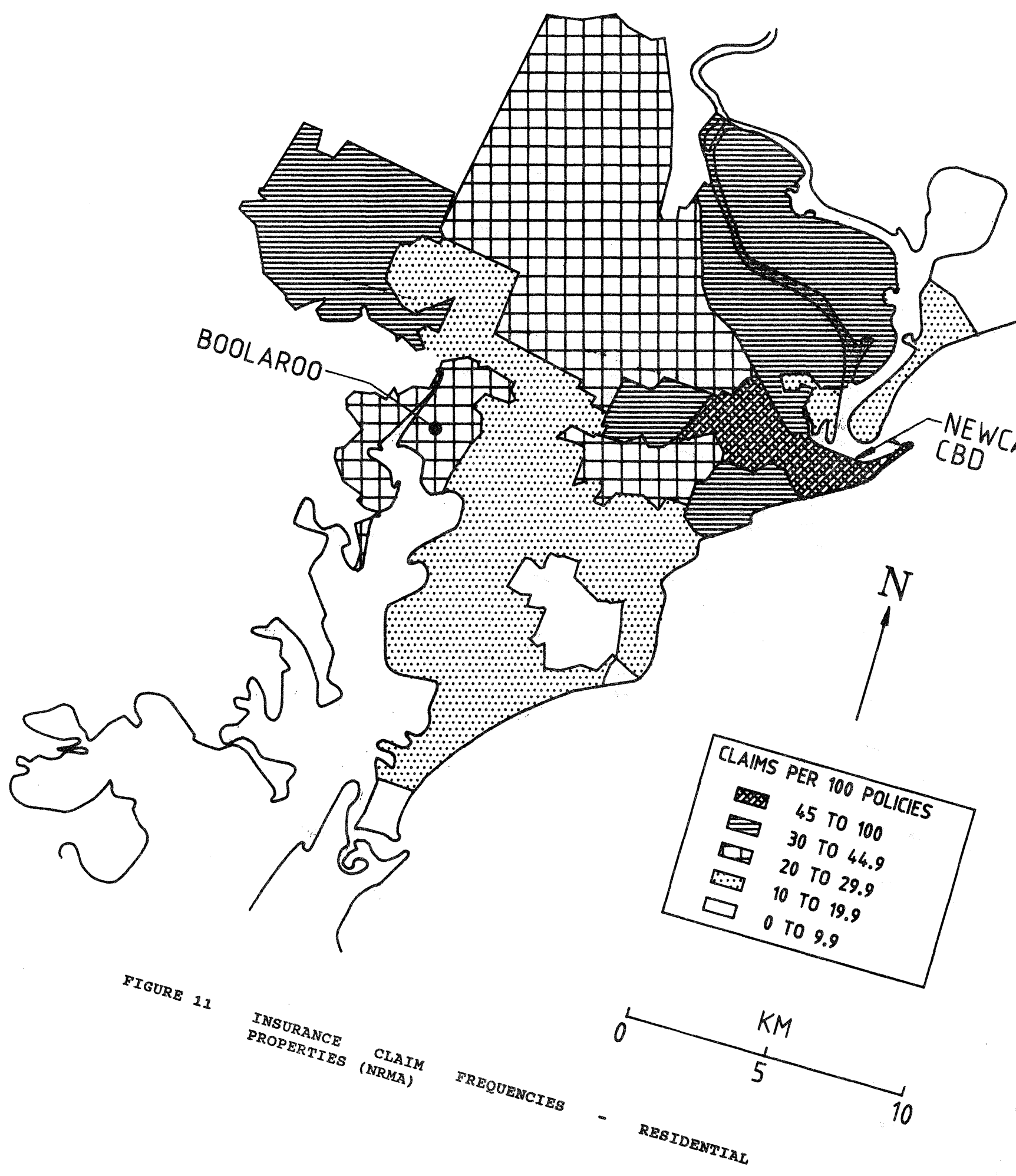


TABLE 2: EARTHQUARE CLAIM FREQUENCY AND VALUE FOR DOMESTIC BUILDINGS AS A FUNCTION OF CLADDING TYPE (NRMA)

cladding Type

Proportion

per 100 Policies
Earthquake claims

per 100 Policies
Average value of claim

(\$A) (a) Newcastle Overall

Brick

Weatherboard

Asbestos Cement and other

b) Hamilton Suburb and other

Brick

Weatherboard plasterwork.

The majority of domestic roofs are constructed of clay tiles on timber framing, and the earthquake caused movement of some tiles and ridge cappings. However in many cases the full extent of tile movement did not become apparent until the heavy rain on February 2-3 which caused a number of roofs to leak.

Problems associated with the common usage of thin sheet metals as damp-proof courses in brick construction were highlighted by this earthquake. For domestic chimneys, the point of translation and in many cases failure was invariably the damp coursing immediately above roof level. Similarly, some walls had displaced longitudinally and/or transversely on the damp coursing over the foundation elements.

There were numerous observations of timber framed houses moving on their foundations by up to $35 \mathrm{~mm}$. In many cases this movement was caused by the poor or non-existent holding down details, with a common detail featuring timber bearers simply resting on sheet metal on brick piers.

A detailed breakdown of damage to residential buildings according to cladding type is summarised in Table 2 , which is also based on preliminary NRMA insurance data. This table includes figures for both the Newcastle region and the inner-city suburb of Hamilton, which was one of the worst affected areas. The greater proportion of brick houses in Hamilton compared to Newcastle overall is indicative of the age of the district. It should be noted that the brick cladding category includes both full-brick and brick veneer/timber frame construction, although the latter combination is not particularly common in the older Hamilton area. The tabulated figures exclude claims for damage to contents, which was generally much less significant than the corresponding building damage.

Brick-clad houses predictably gave rise to the greatest claim frequencies and average values, with the latter figure for Hamilton reflecting both the greater level of damage recorded in this area and the increased nature of damage suffered by some older brick houses as a consequence of the poor condition of mortar and cavity ties. However the claim frequencies for timber-framed buildings were also high, particularly for the region as a whole which incorporates areas beyond the main alluvial basin with much newer building stock. Although the majority of timberframed houses performed well structurally, the deformation of those buildings with heavy clay tile roofs caused appreciable damage in some cases to internal plasterboard linings. The differences in earthquake performance between the construction types as represented in this table are not fully highlighted as there are elements of damage common to all categories such as chimney collapses, often with associated roof and internal distress.

\section{Emergency Facilities and Places of Assembly}

The Royal Newcastle Hospital suffered major damage to two wings constructed early this century. These linked three- and fourstorey reinforced concrete slab and loadbearing brick structures sustained significant diagonal cracking to upper level walls and are now to be demolished, subject to heritage issues being resolved. No injuries resulted from this damage, although patients were immediately evacuated to other 
parts of the hospital. Also of major concern immediately following the earthquake was the condition of the $50 \mathrm{~m}$ high brick chimney to the main hospital boiler. This chimney was in poor condition prior to the earthquake having been the subject of previous repair efforts. After the earthquake a bulge in the brickwork was visible approximately eight metres below the top of the chimney. In this condition it posed a major threat to persons and equipment in the main plantroom below, and the top of the chimney was removed brick by brick down to below the affected section from a mobile platform three days after the earthquake.

older buildings of the private Mater Misericordiae Hospital in the suburb of Waratah also sustained typical distress to masonry elements, with the evacuation of some wards being necessary along with substantial subsequent repairs.

The older masonry regional headquarters of both the fire and ambulance services received moderate structural damage (refer figure 12). although other district stations suffered only non-structural disturbance. It is understood that emergency operations were not significantly affected, but once again illustrates the risks associated with housing key equipment and operations centres in aged buildings of non - ductile construction.
Many churches in Newcastle suffered damage as a result of the earthquake, ranging from minor cracking of walls and arches to severe cracking of some bell towers and spires necessitating demolition. The extent of damage was predictable given the combination of age and use of heavy, tall and often unrestrained brickwork elements.

These were also a large number of school buildings that sustained major damage, with the worst of these being at the cooks Hill, wickham, Tighes Hill, Lambton and The Junction schools (refer figure 8 ). The damage consisted largely of collapsed parapets, chimneys, gables and outer wall skins as described in the section on "Typical Damage Characteristics", in addition to failure of long, unsupported internal partitions. Some of these larger two- and three-storey buildings illustrated the effects of poorly connected and detailed timber diaphragms, with parts of buildings suffering disproportionately large damage. Walls of some gymnasia and other assembly hall buildings over five metres in height displayed signs of out-of-plane flexural cracking. Efforts following the earthquake focussed on carrying out sufficient "firstaid" repairs to schools by the end of January to enable them to open for the new school year. Temporary classroom accommodation was required in many schools.

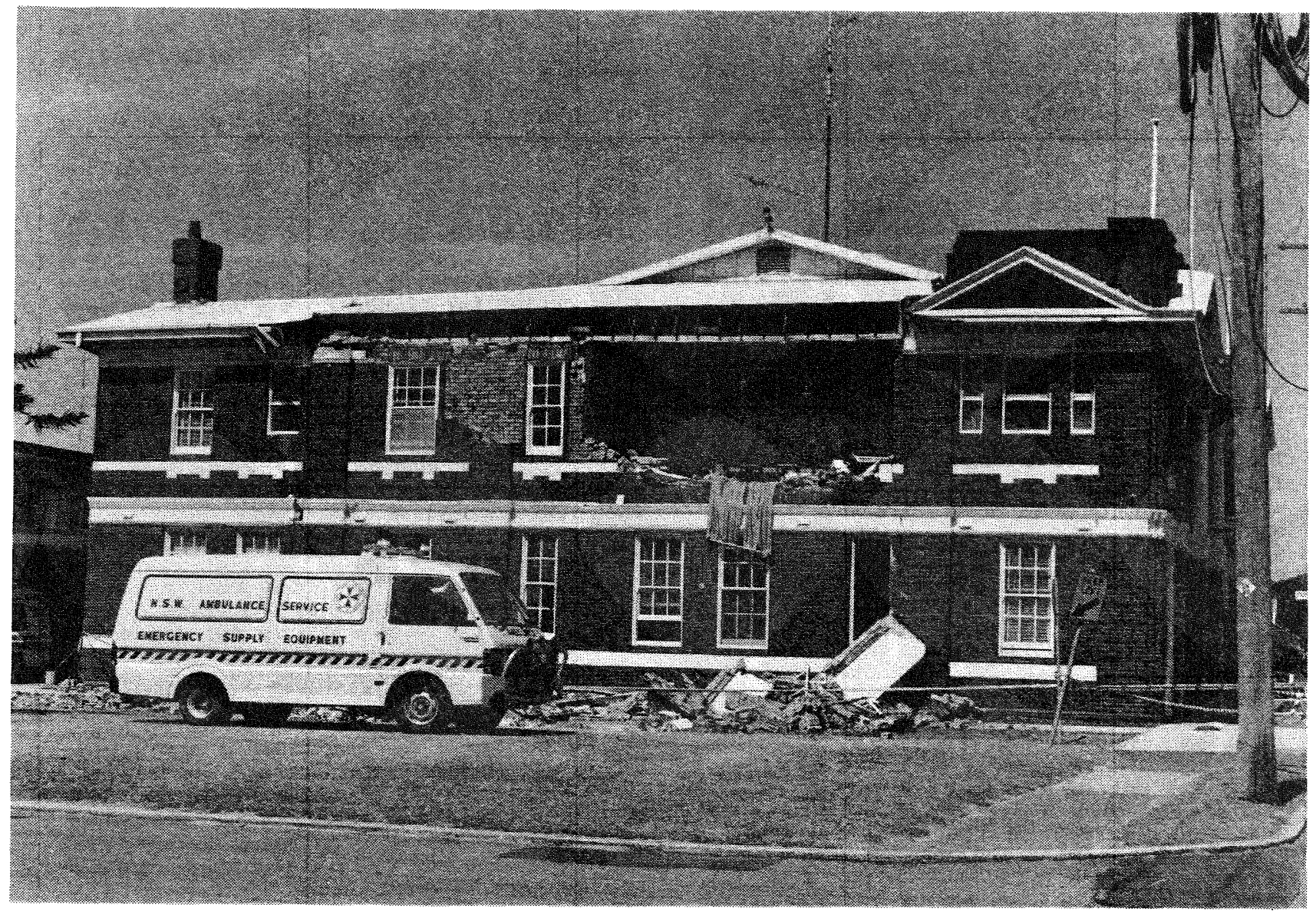




\section{Services}

As noted earlier, there were few recorded cases of either ruptured in-ground services or fallen overhead power wires. However both the grid substation at Killingworth, $20 \mathrm{~km}$ southwest of the centre of Newcastle, and the bulk supply substation at Waratah suffered equipment damage resulting in $a$ two and $a$ half hour interruption in power supply to the general area immediately following the earthquake. Several porcelain mounting insulators beneath switchgear and circuit breakers failed, causing these elements to fall over. The repair bill for this and associated minor damage to wiring etc for these two substations was in excess of one million dollars.

The major BHP steel plant at Mayfield suffered damage to plant and equipment as a result of the loss of power. These were also various reports of both heavy industrial and building services plant items moving off their mountings. With the absence of any requirement or awareness to design mountings for earthquake forces many plant items had only nominal holding-down and restraint fixings. Light fittings weighing several kilograms fell from roof and ceiling mountings in at least two factories. There were no casualties recorded at industrial plants as they were not operating due to holiday shutdowns.

\section{INSURANCE ASPECTS}

Insurance cover for earthquake damage in Australia is provided typically within the standard buildings and contents policies with the individual insurance companies in the same manner as fire, storm or other damage. There is no government regulated earthquake insurance cover as is currently the case in New Zealand. As a result of the Newcastle earthquake it appears likely that pressure will be brought to bear by the reinsurance companies to increase premiums generally.

This event again highlighted the problem of property owners having inadequate levels of insurance cover. A number of the more severely damaged residential and retail buildings more than fifty years old were found to be significantly underinsured. In general the major insurance companies did not invoke the averaging clauses of their contracts for residential properties. In addition, many small and medium size businesses did not have cover for business interruption, and so suffered in this regard either directly from temporary closure or indirectly from access restrictions.

of great concern to the insurance companies were the poor levels of maintenance prior to the earthquake exhibited by many properties. While the extent of the corrosion of brick cavity ties surprised many in the building industry, there were more obvious cases where preventative maintenance would have reduced the magnitude of earthquake damage. The example of expansion cracking in commercial parapets has been cited previously, and some of the collapsed awnings showed signs of advanced corrosion of tie rods and fixings. Similarly it was commonly found that steel arch bars used above doors and windows were in advanced stages of corrosion, with the resulting expansion at the ends acting as an initiator for horizontal cracking under seismic loading.

Drawing a distinction between earthquake damage and existing conditions for premises that had only suffered minor damage posed difficulties for insurance companies. In many cases cracks claimed by owners as earthquake damage in brickwork and concrete had either been present and were increased as a result of the earthquake, or had remained unchanged. This was a consequence of home owners in particular carrying out detailed inspections of their buildings following the earthquake and often noticing for the first time signs of building distress that had in fact been present for several years.

The considerations of insurance requirements along with the absence of any seismic strengthening regulations influenced the nature of the immediate repairs to partially damaged buildings. These repairs, typically to brick parapets and gables of commercial and retail properties, usually only involved reinstatement to the former condition. A related difficulty was the incorrect belief of some owners and tradesmen that the failure of masonry elements was solely due to materials aspects such as degraded mortar or corroded cavity ties rather than more fundamental design issues. The Insurance Council of Australia has expressed reservations that the vast sums of money currently being spent on repair work would in all probability only result in a slightly smaller insurance loss should an event of similar magnitude occur in the future.

\section{THE RESPONSE OF LOCAL AUTHORITIES AND} EMERGENCY SERVICES

The police and local authorities in charge immediately after the earthquake found themselves facing a disaster scenario not previously experienced by a major city in Australia. While the extent of damage was similar to that caused by Cyclone Tracy in Darwin in 1974, the nature of the damage coupled with the uncertainty of aftershocks created a different situation for the authorities.

Although a state of emergency was not declared, control immediately following the earthquake was assumed by the Newcastle Police. The chief Inspector subsequently worked out of the offices of the Newcastle city council alongside the director of health and building services for the week following the earthquake, and this led to a high degree of co-operation between these principal authorities. The army demolition squad was also active in some of the worst-hit areas during this period. The state Emergency Service mobilised a large number of volunteers to assist in the immediate "first - aid" measures such as removing brickwork 
elements and placing tarpaulins over damaged roofs, operations which contained for several days. The Public Works Department deployed consultant engineers including the representatives from the NZNSEE to check out the safety and stability of the various public buildings in and around Newcastle. This effort initially concentrated on the two main hospitals, being subsequently widened to take in school properties and other institutions.

In the first few days following the earthquake, a significant problem was the wide range of engineering advice received by property owners for all categories of buildings. The immediate reaction of many local engineers was to require the demolition of buildings that had in fact suffered only moderate earthquake damage. This damage often looked to be major, but on closer inspection was found to either affect discrete elements only, such as parapets, awnings and outer brickwork skins, or to not be of structural significance, such as minor cracking of internal walls. Engineering opinions at the opposite end of the scale were also received.

This issue quickly involved several of Newcastle's more prominent heritage - listed buildings, and came to a head with the demolition of a hotel where the historic facade was the subject of a preservation order. The council subsequently required the formal issue of demolition permits for all such activities, which along with an increasing uniformity of engineering opinions, led to a more logical series of actions. However, the legal requirements of some heritage listings were found to be impractical in the circumstances, with the stipulation that facades be reconstructed in their original materials being a prime example. This led to frustration for owners and tradesmen wanting to proceed quickly with repairs.

The centre of Newcastle was cordoned off by police following the earthquake, with the restricted area reducing in size as the damage in the inner suburbs was cleared up. Streets in the Central Business District remained barricaded for a total of ten days until the council was satisfied that all potential risks to members of the public from damaged buildings had been identified and locally barricaded. During this time only council- and police - approved personnel (which included inspecting engineers and insurance assessors) were permitted into the restricted area, with the majority of commercial owners and tenants being excluded. Manning the roadblocks for this length of time proved to be a very onerous task for the police, as there were many people wanting to enter the city centre to inspect their premises, in addition to sightseers from other areas.

The main efforts of the council during this period were concentrated on implementing a notification system for buildings in the CBD and surrounding area. Stickers were created and posted on each building following external inspections by groups of engineers to advise the owners and/or tenants whether or not entry was permitted. The wording for the stickers was based on the californian Applied Technology Council's document ATC-201 "Field Manual: Post earthquake Safety Evaluation of Buildings" [9], with considerable input from the NZNSEE representatives. This document was produced and explained by the society's representatives and, along with first-hand experience of its implementation gained by Bruce shephard following the october 1989 Loma Prieta earthquake, proved invaluable in assisting both the Newcastle city Council and the Public Works Department in establishing evaluation procedures.

The two stickers adopted and their contents can be summarised as follows:

Yellow sticker - Limited access to owners and/or tenants. Report by independent engineer required to be submitted to the council before designation lifted.

Red Sticker - Unsafe to enter or occupy, as the building has been damaged and presents a danger.

Both stickers stated that no demolition or reconstruction work was to be carried out without authorisation from the Town clerk. A green sticker denoting premises that were considered safe to enter was also created, but none were posted following legal advice. As the inspections were external only, it was considered inappropriate to post "safe to enter" stickers until a detailed inspection of the interior had been undertaken by the owners' engineers. The Public Works Department adopted a similar three - sticker system for buildings under its jurisdiction, being able to post green stickers where appropriate following detailed internal and external inspections.

The majority of the council stickers were posted on January 2 and 3 , with groups of volunteer structural engineers walking down all streets in the designated area. It is understood that this process initially caused some friction with the council's building inspectors who had been carrying out their own detailed inspections immediately following the earthquake. This illustrated the important role that local building inspectors have in any post-earthquake safety and damage assessment exercise, given their familiarity with the buildings in question.

All buildings in the CBD received either yellow or red stickers, which meant that many buildings were not readily accessible by owners and/or tenants. The absolute nature of the red sticker meant technically that occupiers were not allowed back inside badly damaged premises either to secure valuable possessions in the first instance, or remove them subsequently prior to demolition. This created particular problems for premises where fresh and frozen food was stored, with 
the removal of some food not taking place for up to ten days. The health issues and logistical difficulties associated with these operations resulted in the council's health inspectors carrying out much of this work directly.

In the weeks that followed the re-opening of the CBD, the Newcastle City Council experienced difficulty in tracking down absentee owners of some damaged commercial properties in order to obtain detailed engineering reports, and in some cases, issue demolition orders. This meant that local barricading remained in place around several buildings for several months, and highlighted the need for local authorities to have a current list of owners or agents for all premises.

A related problem involved some owners of retail and commercial properties who were significantly underinsured. By early April several damaged buildings in the badly - hit Beaumont street in Hamilton had no action taken on them by their owners, who were apparently still assessing their options. The city council was proceeding to serve notices on these owners, in some cases requesting demolition, and preparing to take direct action on behalf of non-responding owners.

\section{POSSIBLE CHANGES TO BUILDING REGULATIONS}

The Australian earthquake code, AS2121 had been under review for several months prior to the Newcastle earthquake. When re-issued in approximately two years time this document will formally comprise part of the AS1170 loadings code series. Member design and detailing requirements will be incorporated in updated versions of the various materials codes, as in New Zealand and other countries.

As a part of this review, certain seismic zone changes were under consideration as a result of new earthquake risk maps compiled in 1987 by the Australian Seismological Centre of the Bureau of Mineral Resources. Among these was a proposal to include the Newcastle region in a revised zone $A$ area around Sydney. This would require nonductile construction to be designed for specified lateral forces, including parts of buildings and mechanical/electrical plant fixings, as outlined previously in section 4.

The 1989 Newcastle earthquake has confirmed the need for re-zoning the area, and has again highlighted the significance of microzoning effects such as the presence of alluvial basins. Accordingly it has been suggested that the parts of Newcastle where alluvial deposits are known to be present be further upgraded to a zone 1 classification.

In any event, the Newcastle City Council formally adopted the present earthquake code, AS2121 on March 27, 1990 and further to this has designated the area under its control to be zone $A$. The council has also formulated by-laws requiring owners of existing buildings to secure hazardous masonry elements, using standard securing and restraint details, but to date has been unable to implement them retrospectively for legal reasons.

The limited nature of damage to modern buildings from this event is unlikely to lead to other significant changes to the earthquake code or other building regulations. Similarly there appears to be insufficient economic justification for the introduction of across-the-board legislation requiring existing buildings to be secured or strengthened, despite the major ongoing risk to safety and property that these buildings will pose.

However on a community level it would appear essential to modify the earthquake code requirement that new post-disaster function buildings in zone 2 be of ductile construction to include all such buildings regardless of seismic zoning. Associated with this modification would be a review by experienced earthquake engineers of older existing emergency facilities such as hospitals and ambulance and fire stations, and the implementation of strengthening programmes for these buildings where considered necessary.

\section{LESSONS FOR NET ZEALAND}

While there are few structural engineering design lessons from this earthquake to be noted by New Zealand, there are points relating to local geotechnical influences and local authority organisational matters worth highlighting.

The Newcastle earthquake illustrated again the influence that the surface geology can have on the response of structures. While the Mexican earthquake in particular emphasised the resonance problems experienced by multi-storey structures founded above soft marine or deep alluvial deposits (10), this earthquake confirmed that the response of even small domestic structures can be significantly influenced by the amplification of ground motion due to the presence and depth of such materials. This event therefore serves as further endorsement of the recommendations of the NZNSEE's Mexican earthquake reconnaissance team that microzoning studies be undertaken of areas of New Zealand cities where deep alluvial and marine sediments are known to be present (10).

Although New Zealand authorities in the form of the Civil Defence network are better prepared for major earthquakes than their Newcastle counterparts were, the following organisational issues should be emphasised:

(i) the need for all emergency services and government agencies to be totally familiar with the "disaster plan" to be deployed by the local authority in charge. Included in this plan should be identification of the individual(s) responsible for making decisions regarding the demolition of badly damaged public and private buildings. 
(ii) the need for the methods and systems to be used for immediate post - event engineering inspections to be understood by all beforehand.

(iii) the importance of local authorities having a regularly updated file of the addresses and contact numbers of owners and/or agents of all CBD premises for access, authorisation etc during and subsequent to the immediate emergency phase.

The level of underinsurance of New Zealand domestic, industrial and older commercial properties is likely to parallel that noted in Newcastle and Australia in general, where a number of individuals and companies have suffered significant losses. While this situation should improve in New Zealand with the requirement that all domestic dwellings must have replacement disaster insurance from 14 July 1990, the need for all policies to be indexed for inflation should be re-iterated. similarly owners and tenants of retail and commercial properties of all sizes should be made aware of the importance of having adequate levels of cover for business interruption.

Programmes undertaken by local authorities in New Zealand to secure hazardous unreinforced masonry elements in commercial centres suggests that early masonry buildings in New Zealand would suffer considerably less damage than those in Newcastle for an earthquake of similar intensity. Damage to New Zealand domestic property for a comparable event would also be less as a consequence of the difference in construction type and age.

\section{SUMMARY}

The Newcastle earthquake was a relatively minor seismic event in terms of magnitude and intensity, with the nature of damage being generally predictable given the predominant type and age of construction. Although the list of human casualties was also small compared to other recent international earthquakes, it should be noted that but for the fortuitous timing in the christmas - New Year holiday period, the casualty list would probably have been much greater.

The main significance of this earthquake was that it occurred in a major metropolitan area that had little expectation of such an event, and correspondingly little preparation. As Australia does not lie on or adjacent to the active fault zones of the Pacific rim, it is considered to be a country of low seismic risk. While large earthquakes have occurred at various locations around the continent, this was the first to strike a heavily populated area. This event has illustrated that the risk of damage and human casualties resulting from earthquakes in Australia can no longer be regarded as insignificant.
The degree of amplification of ground motions by the surface layers was a notable characteristic of this earthquake, with a good correlation apparent between the location of greatest building damage and the area of deep alluvial material. However building damage generally was influenced by poor original construction detailing for lateral loading and a lack of ongoing maintenance.

The difficulties associated with earthquake monitoring in Australia have been highlighted by this event. The general perception of Australia as a country of low seismic risk in addition to the size of the continent has resulted in an inadequate monitoring network, as evidenced by the total absence of strong motion data from this earthquake. It is hoped that the incentive now exists to establish mini-networks of seismographs and accelerographs in each major centre in Australia.

\section{REFERENCES}

1. McCue K., et al, "A century of Earthquakes in the Dalton - Gunning Region of New South Wales," Bureau of Mineral Resources Journal of Australia Geology and Geophysics, 11, 1-9, 1989.

2. Mccue K., Wesson V., and Gibson G., "The Newcastle NSW Earthquake of 28 December 1989", Bureau of Mineral Resources Journal of Australia Geology and Geophysics, in press.

3. The Institution of Engineers, Australia, "Newcastle Earthquake Study," Report for N.S.W. State Govt, (Ed.) Melchers R.E., March 1990

4. Australian Bureau of Mineral Resources Earthquake Data File.

5. Standards Association of Australia, "SAA Earthquake Code," AS2121: 1979.

6. Standards Association of Australia, "SAA Concrete Structures Code," AS 1480:1982.

7. Standards Associations of Australia "Concrete Structures", AS3600:1988.

8. Standards Association of New Zealand, "Code of Practice for General structural Design and Design Loadings for Buildings," NZS4203:1984.

9. Applied Technology Council, "Field Manual: Post earthquake Safety Evaluation of Buildings", Committee ATC20-1, Redwood City, California, 1989.

10 Butcher G., et al, "The september 1985 Mexico Earthquakes: Final Report of the New Zealand Reconnaissance Team," Bull. NZNSEE, Vol. 21, No. 1, pp 3-96, March 1988 . 